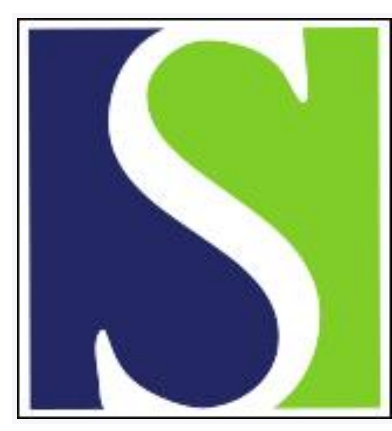

Scand J Work Environ Health 1994;20(2):139-145

https://doi.org/10.5271/sjweh.1419

Issue date: 01 Apr 1994

Psychosocial stressors at work and musculoskeletal problems. by Houtman IL, Bongers PM, Smulders PG, Kompier MA

Affiliation: TNO Institute of Preventive Health Care, Leiden, The Netherlands.

This article in PubMed: www.ncbi.nlm.nih.gov/pubmed/8079136 


\title{
Psychosocial stressors at work and musculoskeletal problems
}

\author{
by Irene LD Houtman, PhD, Paulien M Bongers, PhD, Peter GW Smulders, PhD, \\ Michiel AJ Kompier, $\mathrm{PhD}^{1}$
}

\begin{abstract}
HOUTMAN ILD, BONGERS PM, SMULDERS PGW, KOMPIER MAJ. Psychosocial stressors at work and musculoskeletal problems. Scand J Work Environ Health 1994;20:139-45.

OBJEctives - This paper examines the relationship between work stressors and the following health indicators: psychosomatic complaints, health behavior, and musculoskeletal problems.

Methods - Secondary analyses were performed on data from the National Work and Living Condition Survey, which provides a representative sample of the working population in The Netherlands. The survey was made in 1977, 1983, and 1986 by The Netherlands Central Bureau of Statistics. By means of factor analysis the following three risk dimensions were identified in the survey: work pace, intellectual discretion, and physical stressors.

Results - High work pace, low intellectual discretion, and physical stressors were associated with increased health complaints (both psychosomatic and musculoskeletal) and musculoskeletal disorders after adjustment for gender, age, education, and sports participation. Low intellectual discretion, but not high work pace, was associated with poor general health and health behavior indicative of poor health. Physical stressors were associated with general health as well, but not with health behavior, except for reported absenteeism.

Conclusions - Psychosocial stressors are not only associated with psychosomatic complaints and health indicators, but also with musculoskeletal problems, both acute and chronic. Especially the relation between intellectual discretion and musculoskeletal problems can be partly attributed to physical load. Even after adjustment for physical stressors and moderating personal characteristics, the relationships between the psychosocial stressors and musculoskeletal problems remained significant and comparable in strength to the relationship between psychosocial stressors and several other health outcomes, such as psychosomatic complaints.
\end{abstract}

KEY TERMS - health behavior, musculoskeletal problems, psychosomatic complaints, work stressors.

It has often been demonstrated that psychosocial stressors at work are related to depressive symptoms and psychological dysfunctioning $(1,2)$ and also to health behavior such as use of medication, doctor's visits, and sickness absenteeism $(1,3)$. Psychosocial stressors at work have been found to be related to cardiovascular pathology (4-8), diseases of immunologic origin $(9,10)$, and, recently, to musculoskeletal problems as well (11). The relationship between psychosocial stressors and psychological dysfunctioning, as well as the relationship between psychosocial problems and musculoskeletal problems, is especially interesting, since these two health problems constitute the main reasons for disablement among two-thirds of the population diagnosed as disabled for work in The Netherlands. [Each type of diagnosis accounts for about one-third of the working population diagnosed as disabled (12).] Not only psychological dysfunctioning but also musculoskeletal

TNO Institute of Preventive Health Care, Leiden, The Netherlands.

Reprint requests to: Dr ILD Houtman, TNO Institute of Preventive Health Care, PO Box 124, 2300 AC Leiden, The Netherlands. problems, especially back pain, are considered to be important problems associated with poor well-being, the use of medical care, and restriction of activities or absenteeism at work in other countries as well (13). Although the relationship between psychosocial stressors and psychological (dys)functioning has been studied extensively and models of stress and indicators of psychological health have been constructed (1), research on the relationship between psychosocial stressors and musculoskeletal problems has been very limited. Positive evidence of a relationship between psychosocial stressors at work and musculoskeletal problems will, however, provide interesting options for preventive actions aimed at saving costs through a reduction in complaints, absenteeism, and, perhaps, even disability due not only to psychological dysfunctioning but also to musculoskeletal problems.

A recent review shows that studies on the relationship between psychosocial stressors and musculoskeletal problems are heterogeneous, both with respect to the independent variable and the outcome variable (11). No clear picture exists as to which psychosocial stressors are the most strongly related to musculoskeletal problems, if this relationship is a causal one, as to how specific the relationship is with 
respect to the type of musculoskeletal problem (back pain or other musculoskeletal problems, chronic or acute effects) and if nonwork activities like sports confound the relationship. Several mechanisms have been proposed. Psychological and physiological explanations have been put forward that suggest that psychosocial loads might either change the perception of pain (14) or induce physiological changes that might result in musculoskeletal problems (11). A methodological explanation might, however, apply as well (11). Although there might be a direct relationship between psychosocial stressors (eg, work pace and monotony) and musculoskeletal problems, the relationship might well be confounded by physical stressors such as static load or repetitive work.

In the present study, an analysis was performed on a representative sample of a cross-section of the Dutch working population. The study was descriptive in nature and aimed at determining the relationship between psychosocial stressors at work and sev-

Table 1. Variables used in the study.

\begin{tabular}{|c|c|}
\hline Variable & Scoring range \\
\hline \multicolumn{2}{|l|}{ Psychosocial and physical stressors at work } \\
\hline \multicolumn{2}{|l|}{ Psychosocial stressors } \\
\hline $\begin{array}{l}\text { High work pace } \\
\text { Monotonous work } \\
\text { Poor possibilities for personal } \\
\text { development } \\
\text { Poor fit between work and experience } \\
\text { or education } \\
\text { Poor prospects of promotion }\end{array}$ & $\begin{array}{l}1=\text { no, } 2=\text { yes } \\
1=\text { no, } 2=\text { yes } \\
1=\text { no, } 2=\text { yes } \\
1=\text { no, } 2=\text { yes } \\
1=\text { no, } 2=\text { yes }\end{array}$ \\
\hline \multicolumn{2}{|l|}{ Physical stressors } \\
\hline $\begin{array}{l}\text { Dangerous work } \\
\text { Heavy physical load } \\
\text { Noise at work } \\
\text { Dirty work } \\
\text { Bad smell at work }\end{array}$ & $\begin{array}{l}1=\text { no, } 2=\text { yes } \\
1=\text { no, } 2=\text { yes } \\
1=\text { no, } 2=\text { yes } \\
1=\text { no, } 2=\text { yes } \\
1=\text { no, } 2=\text { yes }\end{array}$ \\
\hline \multicolumn{2}{|l|}{ Health } \\
\hline Opinion on health in general & $\begin{aligned} 1 & =\text { well/very well } \\
2 & =\text { moderate/not so } \\
& \text { well/bad }\end{aligned}$ \\
\hline Psychosomatic complaints & $0-13$ \\
\hline $\begin{array}{l}\text { Stay ill at home during past three } \\
\text { months (absenteeism) }\end{array}$ & $1=$ no, $2=$ yes \\
\hline $\begin{array}{l}\text { Doctor's visit during past three months } \\
\text { (doctor's visit) }\end{array}$ & $1=$ no, $2=$ yes \\
\hline Use of medication (excluding contraceptives) & $1=$ no, $2=$ yes \\
\hline Back-pain complaints & $1=$ no, $2=$ yes \\
\hline Complaints about muscles and joints & $1=$ no, $2=$ yes \\
\hline $\begin{array}{l}\text { Back problems (chronic), including hernia } \\
\text { (last year, more than three months or } \\
\text { at least three times in this period) }\end{array}$ & $1=$ no, 2 = yes \\
\hline \multicolumn{2}{|l|}{ Confounding variables } \\
\hline Gender & $1=$ male, $2=$ fernale \\
\hline Age & $\begin{array}{l}1=18-34 \text { years } \\
2=35-54 \text { years } \\
3=\geq 55 \text { years }\end{array}$ \\
\hline Educational level & $\begin{aligned} 1= & \text { primary education } \\
& \text { or less } \\
2= & \text { lower professional } \\
& \text { education and lower } \\
& \text { secondary educa- } \\
& \text { tion } \\
3= & \text { higher secondary } \\
& \text { education } \\
4= & \text { higher professional } \\
& \text { training and } \\
& \text { university }\end{aligned}$ \\
\hline Sports participation & $1=y e s, 2=$ no \\
\hline
\end{tabular}

eral indicators of health, including psychosomatic complaints, health behavior, and acute and more chronic musculoskeletal problems. The study attempted to examine both the specificity of the relationship between psychosocial stressors at work and health outcomes and to test the possible confounding effect of physical load on the relationship between psychosocial stressors and musculoskeletal problems, while adjusting for several confounding personal characteristics.

\section{Subjects and methods}

The National Work and Living Condition Survey was administered by the Central Bureau of Statistics (CBS) to a representative sample of the working population in The Netherlands once every three years in 1977-1986 (15). The total sample consisted of 5865 employees aged 18 to 65 years. The representativeness of each sample has been corroborated in a comparison of the distribution of employees across occupations and company types with that of another CBS survey, directed at estimating the magnitude of the Dutch labor force (16). In an attempt to improve the reliability of the results, the different samples across time were pooled. The pooling was considered to be justified since the interrelations of the different variables were found to be stable across the years $(17,18)$.

Table 1 shows the variables used in the study, including psychosocial and physical stressors at work (independent variables), health outcomes (dependent variables), and personal characteristics (confounding variables). All questions on stressors at work in the survey were used in the analyses for this study, except the question on shift work. With respect to the personal characteristics, gender, age, and education are known to be important potential moderators in the relationship between psychosocial and physical stressors at work and health outcomes. These three characteristics were used, including sports participation as well. Sports participation was considered especially interesting since it has not only been found to be beneficial for well-being (19), but it might be positively related to musculoskeletal problems, especially of the limbs.

The relationships between stressors and health indicators were studied with multiple logistic regression analyses. Since the mutual independence of the stressors at work were not empirically established, a factor analysis (Varimax rotation) was first performed on these stressors to identify possible underlying stressor dimensions. It was expected that a factor analysis would identify dimensions which would have more theoretical relevance than the individual stressors. Although the regressions of the dimensions to be extracted from the health indicators might be interesting from a theoretical perspective, the dimensions to be extracted would probably explain only 
part of the variance explained by the individual stressors in the survey. Therefore, the regression analyses were performed on both individual stressors and underlying dimensions of stress risk.

Multiple logistic regression analyses performed with the individual stressors (all dichotomous variables) as independent variables result in an odds ratio for each stressor, indicating the relative chance that the health indicator is present when the stressor is present, when the other independent and confounding variables are adjusted for in the regression model. When these logistic regressions are applied to the dimensions extracted from the factor analysis, the independent parameter is no longer dichotomous but has a scoring range from zero to the number of stressors that constitute the dimension. The odds ratio of a stressor dimension indicates the chance that a particular health indicator is present when one, two, three, or more (up to the maximum number of stressors in the dimension) stressors of the dimension are present relative to the situation in which all stressors of that dimension are absent.

\section{Results}

The factor analysis of the stressors resulted in the following three independent factors, explaining $45 \%$ of the variance of the individual stressors: (i) work pace (Eigenvalue $=1.02$ ), (ii) intellectual discretion (consisting of monotonous work, poor possibilities for personal development, poor fit between the actual work and education or experience level, and poor promotional prospects) (Eigenvalue $=1.62$, Cronbach $\alpha=0.55$, factor loadings ranging from 0.56 to 0.77 , indicating an acceptable homogeneity and rather equivalent contribution of the individual stressors), and (iii) physical stressors (heavy physical work, bad smell at work, dirty work, noise at work, dangerous work) (Eigenvalue $=2.27$, Cronbach $\alpha=0.63$, factor loadings ranging from 0.59 to 0.71 , indicating an acceptable homogeneity and rather equivalent contribution of the individual stressors).

Table 2 shows the percentage of employees said to have been confronted with a specific stressor, as well as the prevalence of the health indicators. A summary score was calculated only for the psychosomatic complaints. The stress dimensions are also shown in this table.

The odds ratios and confidence intervals for the individual stressors for each of the health indicators, estimated on the basis of the multiple logistic regression analyses, are presented in table 3 . In table 4 , the estimated odds ratios and confidence intervals are presented for the three risk dimensions which resulted from the factor analysis. Tables 3 and 4 indicate that a high work pace was positively related to psychosomatic complaints, as well as to complaints of back pain and muscle and joint complaints. A high work pace was, however, unrelated
Table 2. Mean percentages of confirmatory answers to questions about the presence of individual risk factors for work stress and health, across 1977, 1983, and 1986. Only the psychosomatic complaint score is a summary score.

\begin{tabular}{lc}
\hline Variable & $\begin{array}{c}\text { Percentage } \\
\text { yes }\end{array}$ \\
\hline Stressors at work & \\
Work pace & 42 \\
$\quad$ High work pace & \\
Intellectual discretion & 17 \\
Monotonous work & 35 \\
Poor opportunities for personal development & 30 \\
Poor fit between work and experience or education & 67 \\
Poor prospects of promotion & \\
Physical stressors & 9 \\
$\quad$ Dangerous work & 22 \\
Heavy physical load & 25 \\
Noise at work & 24 \\
Dirty work & 10 \\
Bad smell at work & \\
Opalth & 14 \\
Psychosomatic complaints & 2.1 a \\
III at home & 31 \\
Doctor's visit & 37 \\
Back-pain complaints & 28 \\
Complaints about muscies and joints & 25 \\
Back problems (chronic) & 24 \\
\hline a Mean score, not percentage. & 8 \\
\hline
\end{tabular}

to a feeling of health in general and to the health behavior factors.

Poor intellectual discretion, especially monotonous work, was related to all of the indicators of health, including all of the indicators of musculoskeletal problems. Table 4 shows that the health problems steadily increased with an increasing number of indicators for poor intellectual discretion. Physical stressors, especially heavy physical work, were positively related to most of the health indicators, especially back problems. The odds ratios for the back problems were relatively high, mainly due to the explanatory power of physically heavy work.

The estimated odds ratios for the personal characteristics are shown in table 3 but, for efficiency, not in table 4 . The odds ratios for the individual characteristics were found to be about the same when they were entered into the model either with the individual stressors (table 3 ) or with the risk dimensions (table 4).

The women reported more health complaints and more doctor's visits and use of medication than the men, as did more of the older employees than the younger ones. Older employees, on the other hand, less frequently reported having stayed home ill during the last three months. Sports participation was positively associated with a feeling of good health in general but not with other indicators of health.

When physical stressors and personal characteristics were entered stepwise into the logistic model, a stepwise reduction in the estimated odds ratios of the intellectual discretion dimension was observed (table 5). As has been shown in tables 3 and 4, in which the results from the most extensive regression 
Table 3. Estimated odds ratios (OR) of the individual risk factors for the different health indicators. The odds ratios indicate the health risk associated with the independent variable as opposed to the situation in which this variable was absent, all other variables being adjusted for in the logistic model. $(95 \% \mathrm{Cl}=95 \%$ confidence interval)

\begin{tabular}{|c|c|c|c|c|c|c|c|c|c|c|c|c|c|c|c|c|}
\hline \multirow[t]{2}{*}{ Variable } & \multicolumn{2}{|c|}{$\begin{array}{c}\text { Health } \\
\text { (general) }\end{array}$} & \multicolumn{2}{|c|}{$\begin{array}{l}\text { Psychosomatic } \\
\text { symptoms }\end{array}$} & \multicolumn{2}{|c|}{ Absenteeism } & \multicolumn{2}{|c|}{$\begin{array}{l}\text { Doctor's } \\
\text { visit }\end{array}$} & \multicolumn{2}{|c|}{$\begin{array}{l}\text { Use of } \\
\text { medication }\end{array}$} & \multicolumn{2}{|c|}{$\begin{array}{c}\text { Back } \\
\text { complaints }\end{array}$} & \multicolumn{2}{|c|}{$\begin{array}{c}\text { Muscle or } \\
\text { joint complaints }\end{array}$} & \multicolumn{2}{|c|}{$\begin{array}{l}\text { Back problems } \\
\text { (chronic) }\end{array}$} \\
\hline & OR & $95 \% \mathrm{Cl}$ & OR & $95 \% \mathrm{Cl}$ & OR & $95 \% \mathrm{Cl}$ & OR & $95 \% \mathrm{Cl}$ & OR & $95 \% \mathrm{Cl}$ & OR & $95 \% \mathrm{Cl}$ & OR & $95 \% \mathrm{Cl}$ & OR & $95 \% \mathrm{Cl}$ \\
\hline \multicolumn{17}{|l|}{ Work pace } \\
\hline High work pace & 1.14 & $0.95-1.35$ & 1.50 & $1.32-1.70$ & 1.10 & $0.97-1.24$ & 1.00 & $0.88-1.12$ & 1.12 & $0.99-1.28$ & 1.21 & $1.06-1.39$ & 1.29 & $1.12-1.49$ & 1.20 & $0.93-1.54$ \\
\hline \multicolumn{17}{|l|}{ Intellectual discretion } \\
\hline $\begin{array}{l}\text { Monotonous work } \\
\text { No good develop- } \\
\text { ment } \\
\text { No proper fit } \\
\text { No good promotion }\end{array}$ & $\begin{array}{l}1.62 \\
1.26 \\
1.21 \\
1.23 \\
1.23\end{array}$ & $\begin{array}{l}1.28-2.04 \\
1.04-1.53 \\
1.00-1.47 \\
1.00-1.52\end{array}$ & $\begin{array}{l}0.98 \\
1.23 \\
1.14\end{array}$ & $\begin{array}{l}1.34-1.95 \\
0.84-1.30 \\
1.07-1.42 \\
0.99-1.32\end{array}$ & $\begin{array}{l}1.17 \\
1.13 \\
1.05\end{array}$ & $\begin{array}{l}1.01-1.34 \\
0.98-1.29 \\
0.91-1.21\end{array}$ & $\begin{array}{l}1.00 \\
1.05 \\
1.04\end{array}$ & $\begin{array}{l}1.14-1.64 \\
0.87-1.15 \\
0.92-1.21 \\
0.90-1.18\end{array}$ & $\begin{array}{l}1.22 \\
\\
1.06 \\
1.07 \\
1.12\end{array}$ & $\begin{array}{l}1.01-1.47 \\
0.92-1.23 \\
0.92-1.24 \\
0.97-1.29\end{array}$ & $\begin{array}{l}1.00 \\
1.13 \\
1.05\end{array}$ & $\begin{array}{l}0.86-1.17 \\
0.97-1.31 \\
0.86-1.23\end{array}$ & $\begin{array}{l}1.04 \\
1.19 \\
1.04\end{array}$ & $\begin{array}{l}0.88-1.21 \\
1.02-1.39 \\
0.89-1.22\end{array}$ & $\begin{array}{l}1.15 \\
1.21 \\
1.23\end{array}$ & $\begin{array}{l}0.87-1.51 \\
0.92-1.59 \\
0.89-1.69\end{array}$ \\
\hline \multicolumn{17}{|l|}{ Physical stressors } \\
\hline $\begin{array}{l}\text { Physically heavy } \\
\text { work } \\
\text { Noise } \\
\text { Dirty work } \\
\text { Bad smell at work } \\
\text { Dangerous work }\end{array}$ & $\begin{array}{l}1.23 \\
1.15 \\
1.00 \\
1.27 \\
1.14\end{array}$ & $\begin{array}{l}0.98-1.53 \\
0.93-1.41 \\
0.80-1.26 \\
0.97-1.68 \\
0.86-1.53\end{array}$ & $\begin{array}{l}1.32 \\
1.23 \\
0.91 \\
1.40 \\
1.27\end{array}$ & $\begin{array}{l}1.12-1.56 \\
1.06-1.44 \\
0.76-1.08 \\
1.13-1.74 \\
1.02-1.58\end{array}$ & $\begin{array}{l}1.23 \\
1.16 \\
0.83 \\
1.20 \\
1.10\end{array}$ & $\begin{array}{l}1.05-1.44 \\
1.00-1.35 \\
0.70-0.99 \\
0.97-1.49 \\
0.88-1.36\end{array}$ & $\begin{array}{l}1.21 \\
1.15 \\
0.99 \\
1.07 \\
0.99\end{array}$ & $\begin{array}{l}1.03-1.41 \\
0.99-1.32 \\
0.84-1.17 \\
0.87-1.32 \\
0.80-1.22\end{array}$ & $\begin{array}{l}1.09 \\
1.11 \\
0.91 \\
1.16 \\
1.18\end{array}$ & $\begin{array}{l}0.92-1.29 \\
0.95-1.29 \\
0.76-1.08 \\
0.93-1.45 \\
0.94-1.48\end{array}$ & $\begin{array}{l}1.62 \\
1.10 \\
1.22 \\
1.19 \\
1.19\end{array}$ & $\begin{array}{l}1.36-1.91 \\
0.93-1.29 \\
1.02-1.46 \\
0.95-1.50 \\
0.95-1.50\end{array}$ & $\begin{array}{l}1.61 \\
1.25 \\
0.93 \\
1.38 \\
1.28\end{array}$ & $\begin{array}{l}1.35-1.92 \\
1.06-1.47 \\
0.77-1.12 \\
1.10-1.74 \\
1.01-1.61\end{array}$ & $\begin{array}{l}1.36 \\
0.99 \\
1.09 \\
1.59 \\
1.22\end{array}$ & $\begin{array}{l}1.00-1.85 \\
0.73-1.35 \\
0.78-1.52 \\
1.08-2.34 \\
0.80-1.85\end{array}$ \\
\hline \multicolumn{17}{|l|}{$\begin{array}{l}\text { Confounding } \\
\text { variables }\end{array}$} \\
\hline $\begin{array}{l}\text { Gender (reference: } \\
\text { male) }\end{array}$ & 1.23 & $1.01-1.48$ & 2.22 & $1.93-2.54$ & 1.12 & $0.98-1.28$ & 1.70 & $1.49-1.94$ & 1.44 & $1.26-1.66$ & 1.57 & $1.35-1.82$ & 1.64 & $1.41-1.91$ & 1.19 & $0.91-1.56$ \\
\hline \multicolumn{17}{|l|}{$\begin{array}{l}\text { Age (reference: } \\
<35 \text { years) }\end{array}$} \\
\hline $\begin{array}{l}35-54 \text { years } \\
\geq 55 \text { years }\end{array}$ & $\begin{array}{l}1.66 \\
3.39\end{array}$ & $\begin{array}{l}1.37-2.02 \\
2.54-4.54\end{array}$ & $\begin{array}{l}1.30 \\
1.60\end{array}$ & $\begin{array}{l}1.14-1.49 \\
1.25-2.06\end{array}$ & $\begin{array}{l}0.77 \\
0.78\end{array}$ & $\begin{array}{l}0.67-0.87 \\
0.61-1.01\end{array}$ & $\begin{array}{l}0.98 \\
1.33\end{array}$ & $\begin{array}{l}0.86-1.11 \\
1.05-1.68\end{array}$ & $\begin{array}{l}1.29 \\
2.21\end{array}$ & $\begin{array}{l}1.12-1.48 \\
1.74-2.80\end{array}$ & $\begin{array}{l}1.65 \\
1.69\end{array}$ & $\begin{array}{l}1.43-1.91 \\
1.29-2.21\end{array}$ & $\begin{array}{l}2.20 \\
3.97\end{array}$ & $\begin{array}{l}1.89-2.55 \\
3.08-5.12\end{array}$ & $\begin{array}{l}2.29 \\
2.20\end{array}$ & $\begin{array}{l}1.74-3.01 \\
1.37-3.54\end{array}$ \\
\hline \multicolumn{17}{|l|}{$\begin{array}{l}\text { Educational level } \\
\text { (reference: } \\
\text { primary school } \\
\text { or less) }\end{array}$} \\
\hline $\begin{array}{l}\text { Level } 2 \\
\text { Level } 3 \\
\text { Level } 4\end{array}$ & $\begin{array}{l}0.76 \\
0.66 \\
0.57\end{array}$ & $\begin{array}{l}0.60-0.98 \\
0.51-0.85 \\
0.42-0.79\end{array}$ & $\begin{array}{l}0.72 \\
0.56 \\
0.54\end{array}$ & $\begin{array}{l}0.59-0.88 \\
0.45-0.68 \\
0.43-0.69\end{array}$ & $\begin{array}{l}0.93 \\
0.84 \\
1.04\end{array}$ & $\begin{array}{l}0.76-1.35 \\
0.69-1.03 \\
0.83-1.31\end{array}$ & $\begin{array}{l}0.79 \\
0.77 \\
0.76\end{array}$ & $\begin{array}{l}0.65-0.95 \\
0.64-0.94 \\
0.61-0.95\end{array}$ & $\begin{array}{l}0.80 \\
0.73 \\
0.84\end{array}$ & $\begin{array}{l}0.65-0.98 \\
0.60-0.90 \\
0.66-1.06\end{array}$ & $\begin{array}{l}0.80 \\
0.69 \\
0.63\end{array}$ & $\begin{array}{l}0.65-0.98 \\
0.56-0.85 \\
0.49-0.81\end{array}$ & $\begin{array}{l}0.90 \\
0.80 \\
0.76\end{array}$ & $\begin{array}{l}0.73-1.11 \\
0.64-0.99 \\
0.59-0.98\end{array}$ & $\begin{array}{l}0.77 \\
0.44 \\
0.56\end{array}$ & $\begin{array}{l}0.54-1.08 \\
0.31-0.63 \\
0.36-0.87\end{array}$ \\
\hline $\begin{array}{l}\text { Sport (reference: } \\
\text { no sport) }\end{array}$ & 0.71 & $0.59-0.86$ & 0.97 & $0.89-1.12$ & 1.06 & $0.92-1.23$ & 1,03 & $0.89-1.18$ & 0.98 & $0.85-1.34$ & 1.07 & $0.91-1.25$ & 0.89 & $0.76-1.04$ & 1.01 & $0.76-1.34$ \\
\hline
\end{tabular}

Table 4. Estimated odds ratios $(O R)$ of the psychosocial risk dimensions for the different health indicators. The odds ratios indicate the health risk associated with the level of the independent variable as opposed to the situation in which this independent variable was absent, all other variables being adjusted for in the logistic model (including personal characteristics; the risks associated with these characteristics are not shown since they do not differ from those in table 3$)$. $(95 \% \mathrm{Cl}=95 \%$ confidence interval)

\begin{tabular}{|c|c|c|c|c|c|c|c|c|c|c|c|c|c|c|c|c|}
\hline \multirow{2}{*}{ Variable } & \multicolumn{2}{|c|}{$\begin{array}{c}\text { Health } \\
\text { (general) }\end{array}$} & \multicolumn{2}{|c|}{$\begin{array}{l}\text { Psychosomatic } \\
\text { symptoms }\end{array}$} & \multicolumn{2}{|c|}{ Absenteeism } & \multicolumn{2}{|c|}{$\begin{array}{c}\text { Doctor's } \\
\text { visit }\end{array}$} & \multicolumn{2}{|c|}{$\begin{array}{c}\text { Use of } \\
\text { medication }\end{array}$} & \multicolumn{2}{|c|}{$\begin{array}{c}\text { Back } \\
\text { complaints }\end{array}$} & \multicolumn{2}{|c|}{$\begin{array}{c}\text { Muscle or } \\
\text { joint complaints } \\
\end{array}$} & \multicolumn{2}{|c|}{$\begin{array}{l}\text { Back problems } \\
\text { (chronic) }\end{array}$} \\
\hline & OR & $95 \% \mathrm{Cl}$ & OR & $95 \% \mathrm{Cl}$ & OR & $95 \% \mathrm{Cl}$ & OR & $95 \% \mathrm{Cl}$ & OR & $95 \% \mathrm{Cl}$ & OR & $95 \% \mathrm{Cl}$ & OR & $95 \% \mathrm{Cl}$ & OR & $95 \% \mathrm{Cl}$ \\
\hline \multicolumn{17}{|l|}{ Work pace } \\
\hline High work pace & 1.15 & $0.97-1.37$ & 1.53 & $1.34-1.72$ & 1.12 & $0.98-1.26$ & 1.01 & $0.90-1.14$ & 1.13 & $1.00-1.29$ & 1.25 & $1.09-1.43$ & 1.33 & $1.15-1.52$ & 1.21 & $0.94-1.56$ \\
\hline \multicolumn{17}{|l|}{$\begin{array}{l}\text { Intellectual } \\
\text { discretion }\end{array}$} \\
\hline $\begin{array}{l}1 \text { stressor } \\
2 \text { stressors } \\
3 \text { stressors } \\
4 \text { stressors }\end{array}$ & $\begin{array}{l}1.48 \\
1.82 \\
2.19 \\
3.18\end{array}$ & $\begin{array}{l}1.13-1.95 \\
1.37-2.42 \\
1.63-2.97 \\
2.17-4.65\end{array}$ & $\begin{array}{l}1.06 \\
1.28 \\
1.37 \\
2.19\end{array}$ & $\begin{array}{l}0.89-1.26 \\
1.06-1.54 \\
1.11-1.69 \\
1.64-2.95\end{array}$ & $\begin{array}{l}1.13 \\
1.30 \\
1.35 \\
1.67\end{array}$ & $\begin{array}{l}0.95-1.33 \\
1.08-1.56 \\
1.10-1.66 \\
1.25-2.23\end{array}$ & $\begin{array}{l}1.10 \\
1.13 \\
1.16 \\
1.54\end{array}$ & $\begin{array}{l}0.93-1.29 \\
0.95-1.35 \\
0.95-1.41 \\
1.17-2.05\end{array}$ & $\begin{array}{l}1.17 \\
1.30 \\
1.28 \\
1.60\end{array}$ & $\begin{array}{l}0.99-1.40 \\
1.08-1.57 \\
1.03-1.57 \\
1.19-2.16\end{array}$ & $\begin{array}{l}0.92 \\
1.11 \\
1.19 \\
1.47\end{array}$ & $\begin{array}{l}0.76-1.11 \\
0.91-1.36 \\
0.95-1.49 \\
1.08-1.99\end{array}$ & $\begin{array}{l}1.00 \\
1.16 \\
1.25 \\
1.67\end{array}$ & $\begin{array}{l}0.82-1.21 \\
0.94-1.42 \\
0.99-1.57 \\
1.22-2.29\end{array}$ & $\begin{array}{l}0.99 \\
1.33 \\
1.44 \\
2.10\end{array}$ & $\begin{array}{l}0.66-1.47 \\
0.88-2.00 \\
0.93-2.30 \\
1.24-3.58\end{array}$ \\
\hline \multicolumn{17}{|l|}{ Physical stressors } \\
\hline $\begin{array}{l}1 \text { stressor } \\
2 \text { stressors } \\
3 \text { stressors } \\
4 \text { stressors } \\
5 \text { stressors }\end{array}$ & $\begin{array}{l}1.35 \\
1.34 \\
1.16 \\
1.89 \\
2.56\end{array}$ & $\begin{array}{l}1.10-1.69 \\
1.03-1.74 \\
0.82-1.65 \\
1.26-2.84 \\
1.47-4.48\end{array}$ & $\begin{array}{l}1.18 \\
1.55 \\
1.39 \\
2.15 \\
2.64\end{array}$ & $\begin{array}{l}1.01-2.95 \\
1.27-1.87 \\
1.08-1.80 \\
1.55-2.98 \\
1.64-4.25\end{array}$ & $\begin{array}{l}1.09 \\
1.19 \\
1.07 \\
1.34 \\
1.83\end{array}$ & $\begin{array}{l}0.93-1.26 \\
0.98-1.44 \\
0.83-1.37 \\
0.97-1.86 \\
1.15-2.93\end{array}$ & $\begin{array}{l}1.17 \\
1.13 \\
1.27 \\
1.40 \\
1.54\end{array}$ & $\begin{array}{l}1.01-1.36 \\
0.94-1.36 \\
1.00-1.62 \\
1.02-1.93 \\
0.96-2.46\end{array}$ & $\begin{array}{l}0.97 \\
1.09 \\
1.06 \\
1.50 \\
1.52\end{array}$ & $\begin{array}{l}0.83-1.14 \\
0.89-1.32 \\
0.82-1.38 \\
1.08-2.09 \\
0.93-2.48\end{array}$ & $\begin{array}{l}1.05 \\
1.50 \\
1.60 \\
3.03 \\
3.90\end{array}$ & $\begin{array}{l}0.88-1.25 \\
1.22-1.84 \\
1.23-2.09 \\
2.19-4.20 \\
2.43-6.27\end{array}$ & $\begin{array}{l}1.25 \\
1.47 \\
1.63 \\
3.37 \\
2.78\end{array}$ & $\begin{array}{l}1.05-1.48 \\
1.19-1.82 \\
1.24-2.13 \\
2.42-4.70 \\
1.70-4.55\end{array}$ & $\begin{array}{l}1.35 \\
1.47 \\
1.54 \\
1.76 \\
4.34\end{array}$ & $\begin{array}{l}0.98-1.85 \\
1.01-2.13 \\
0.95-2.50 \\
0.95-3.26 \\
2.18-8.64\end{array}$ \\
\hline
\end{tabular}

models were shown, the health effects of (poor) intellectual discretion did, however, remain significant. The estimated odds ratios of the physical stressors did not diminish but, instead, increased when the personal characteristics were entered into the model.

\section{Discussion}

One primary conclusion of this study is that a high work pace and poor intellectual discretion, two risk dimensions for work stress which show resemblance to the two main risk dimensions for work stress in 
Table 5. Changes in the estimated odds ratios due to the addition of physical stressors and personal characteristics to the model. (model $1=$ all three risk dimensions and the personal characteristics in the model, model $2=$ only work pace, intellectual discretion and physical stressors in the model, model $3=$ only work pace and intellectual discretion in the model)

\begin{tabular}{|c|c|c|c|c|c|c|c|c|c|c|c|c|c|c|c|c|c|c|c|c|c|c|c|c|}
\hline \multirow{3}{*}{ Variable } & \multicolumn{3}{|c|}{$\begin{array}{c}\text { Health } \\
\text { (general) }\end{array}$} & \multicolumn{3}{|c|}{$\begin{array}{l}\text { Psychosomatic } \\
\text { symptoms }\end{array}$} & \multicolumn{3}{|c|}{ Absenteeism } & \multicolumn{3}{|c|}{$\begin{array}{l}\text { Doctor's } \\
\text { visit }\end{array}$} & \multicolumn{3}{|c|}{$\begin{array}{c}\text { Use of } \\
\text { medication }\end{array}$} & \multicolumn{3}{|c|}{$\begin{array}{c}\text { Back } \\
\text { complaints }\end{array}$} & \multicolumn{3}{|c|}{$\begin{array}{l}\text { Muscle joint } \\
\text { complaints }\end{array}$} & \multicolumn{3}{|c|}{$\begin{array}{l}\text { Back problems } \\
\text { (chronic) }\end{array}$} \\
\hline & Model & Model & Model & Model & Model & Model & Model & Model & Model & Model & Model & Model & Model & Model & Model & Model & Model & Model & Model & Model & Model & Madel & Model & Model \\
\hline & 1 & 2 & 3 & 1 & 2 & 3 & 1 & 2 & 3 & 1 & 2 & 3 & 1 & 2 & 3 & 1 & 2 & 3 & 1 & 2 & 3 & 1 & 2 & 3 \\
\hline Work pace & 1.15 & 1.01 & 1.06 & 1.53 & 1.43 & 1.48 & 1.12 & 1.13 & 1.15 & 1.01 & 1.00 & 1.01 & 1.13 & 1.09 & 1.11 & 1.25 & 1.18 & 1.24 & 1.33 & 1.22 & 1.24 & 1.21 & 1.06 & 1.11 \\
\hline \multicolumn{25}{|l|}{$\begin{array}{l}\text { Intellectual } \\
\text { discretion }\end{array}$} \\
\hline $\begin{array}{l}1 \text { stressor } \\
2 \text { stressors } \\
3 \text { stressors } \\
4 \text { stressors }\end{array}$ & $\begin{array}{l}1.48 \\
1.82 \\
2.19 \\
3.18\end{array}$ & $\begin{array}{l}1.68 \\
2.10 \\
2.69 \\
3.53\end{array}$ & $\begin{array}{l}1.72 \\
2.20 \\
2.83 \\
3.91\end{array}$ & $\begin{array}{l}1.06 \\
1.28 \\
1.37 \\
2.19\end{array}$ & $\begin{array}{l}1.20 \\
1.50 \\
1.79 \\
2.84\end{array}$ & $\begin{array}{l}1.24 \\
1.59 \\
1.90 \\
3.13\end{array}$ & $\begin{array}{l}1.13 \\
1.30 \\
1.35 \\
1.67\end{array}$ & $\begin{array}{l}1.12 \\
1.29 \\
1.39 \\
1.77\end{array}$ & $\begin{array}{l}1.14 \\
1.32 \\
1.43 \\
1.86\end{array}$ & $\begin{array}{l}1.10 \\
1.13 \\
1.16 \\
1.54\end{array}$ & $\begin{array}{l}1.18 \\
1.24 \\
1.35 \\
1.81\end{array}$ & $\begin{array}{l}1.18 \\
1.25 \\
1.36 \\
1.93\end{array}$ & $\begin{array}{l}1.17 \\
1.30 \\
1.28 \\
1.60\end{array}$ & $\begin{array}{l}1.29 \\
1.41 \\
1.45 \\
1.77\end{array}$ & $\begin{array}{l}1.29 \\
1.40 \\
1.46 \\
1.76\end{array}$ & $\begin{array}{l}0.92 \\
1.11 \\
1.19 \\
1.47\end{array}$ & $\begin{array}{l}1.02 \\
1.26 \\
1.45 \\
1.72\end{array}$ & $\begin{array}{l}1.07 \\
1.35 \\
1.58 \\
1.95\end{array}$ & $\begin{array}{l}1.00 \\
1.16 \\
1.25 \\
1.67\end{array}$ & $\begin{array}{l}1.16 \\
1.34 \\
1.51 \\
1.85\end{array}$ & $\begin{array}{l}1.20 \\
1.44 \\
1.62 \\
2.07\end{array}$ & $\begin{array}{l}0.99 \\
1.33 \\
1.44 \\
2.10\end{array}$ & $\begin{array}{l}1.09 \\
1.51 \\
1.84 \\
2.47\end{array}$ & $\begin{array}{l}1.16 \\
1.66 \\
2.01 \\
2.81\end{array}$ \\
\hline \multicolumn{25}{|l|}{$\begin{array}{l}\text { Physical } \\
\text { stressors }\end{array}$} \\
\hline $\begin{array}{l}1 \text { stressor } \\
2 \text { stressors } \\
3 \text { stressors } \\
4 \text { stressors } \\
5 \text { stressors }\end{array}$ & $\begin{array}{l}1.35 \\
1.34 \\
1.16 \\
1.89 \\
2.56\end{array}$ & $\begin{array}{l}1.31 \\
1.37 \\
1.16 \\
1.86 \\
2.33\end{array}$ & : & $\begin{array}{l}1.18 \\
1.55 \\
1.39 \\
2.15 \\
2.64\end{array}$ & $\begin{array}{l}1.18 \\
1.44 \\
1.23 \\
1.83 \\
2.08\end{array}$ & : & $\begin{array}{l}1.09 \\
1.19 \\
1.07 \\
1.34 \\
1.83\end{array}$ & $\begin{array}{l}1.09 \\
1.17 \\
1.02 \\
1.30 \\
1.72\end{array}$ & : & $\begin{array}{l}1.17 \\
1.13 \\
1.27 \\
1.40 \\
1.54\end{array}$ & $\begin{array}{l}1.16 \\
1.06 \\
1.13 \\
1.24 \\
1.28\end{array}$ & i. & $\begin{array}{l}0.97 \\
1.09 \\
1.06 \\
1.50 \\
1.52\end{array}$ & $\begin{array}{l}0.94 \\
1.02 \\
0.95 \\
1.29 \\
1.28\end{array}$ & i. & $\begin{array}{l}1.05 \\
1.50 \\
1.60 \\
3.03 \\
3.90\end{array}$ & $\begin{array}{l}1.04 \\
1.46 \\
1.51 \\
2.82 \\
3.46\end{array}$ & i. & $\begin{array}{l}1.25 \\
1.47 \\
1.63 \\
3.37 \\
2.78\end{array}$ & $\begin{array}{l}1.16 \\
1.35 \\
1.37 \\
2.71 \\
2.15\end{array}$ & $\dot{.}$ & $\begin{array}{l}1.35 \\
1.47 \\
1.54 \\
1.76 \\
4.34\end{array}$ & $\begin{array}{l}1.31 \\
1.53 \\
1.55 \\
1.65 \\
3.91\end{array}$ & $:$ \\
\hline
\end{tabular}

the Karasek model of "job demands-decision latitude" $(1,20)$, were associated with several indicators of health in a cross-section of the Dutch working population. These relationships remained significant even when physical stressors like heavy work load and moderating personal characteristics were adjusted for. A high work pace was an important aspect of job demands, whereas intellectual (or skill) discretion was an aspect of decision latitude. A high work pace was found to be associated with psychosomatic complaints and musculoskeletal problems, including complaints of back pain, joint and muscle problems, and the more chronic back problems. Poor intellectual discretion, especially monotony on the job, was related to a feeling of poor health in general and to several indicators of (ill-) health behavior as well.

The strength of the associations found for both the psychosocial stressors and musculoskeletal problems was comparable with the strength of those found between psychosocial stressors and psychosomatic complaints. This finding suggests that the relationship between the stressors and the health outcomes was either rather nonspecific or might have been the result of a strong interrelationship between the indicators of health in the present study. This last suggestion does not, however, apply since the correlation between the health indicators was rather low; it ranged from 0.17 to 0.47 , the highest correlation being found for the subject's opinion of his or her health in general and psychosomatic complaints.

Other methodological problems, like a lack of reliability of the measurement instruments or fluctuations in time, might have influenced the associations between the psychosocial stressors and health indicators, as well as their (non)specificity. Apart from the fact that the interrelations between the variables in the study remained stable across the years, logistic regressions were also performed on the data of each year in which the survey was administered. Al- though, for some subgroups (eg, employees indicating five physical stressors and having chronic back problems in 1983), the number of cases was extremely small, the results of these analyses indicated that the relationships found for each year were in fairly good agreement with the results of the overall analyses presented in this article.

A criticism that might apply to all of the findings of our study is the fact that the operationalization of both the independent and dependent variables was by way of a self-report instrument. This limitation may have resulted in inflated associations due to "common measure variance." This explanation is, however, not very likely since studies in which relations are reported between survey-based independent variables and more objective indicators of health, like morbidity and mortality figures, show odds ratios or relative risks of comparable magnitude as, or even larger than, those of our study. (See, eg, references 4 and 7.) A recent study in which psychosocial stressors, operationalized by means of a questionnaire, were found to be associated with the results of musculoskeletal function testing by medical doctors has reported risks of comparable magnitude as well (21). The fact that reported stress and health problems in themselves do have significant prognostic value is shown in longitudinal studies in which these variables were found to predict mortality $(22,23)$.

Our findings have theoretical significance. The risk dimensions, found to be associated with the health indicator, did not, however, cover the "job demands-decision latitude" model completely, and generalization of all findings to the entire model is therefore limited. The other aspect of decision latitude, autonomy, was absent in the National Work and Living Condition Survey, as well as another stressor which is considered to be an important risk factor for work stress: social support (24-26). In the "job demands-decision latitude" model, the risk di- 
mensions are assumed to interact and result in a combined health outcome which cannot be solely predicted from a summing of the effects of the two main risk dimensions. A multiplicative interaction of work pace and intellectual discretion was not, however, found to increase the variance in health outcomes in our study. In the literature on the "job demands-decision latitude" model, the interactive effect of the risk dimensions is also under debate. (See, eg, references 27 and 28 for a discussion.) One of the criticisms is that the combined effect of the two risk dimensions for work stress is not best described as multiplicative but as additive, whereas in the latter case the relations may very well be curvilinear. Curvilinearity cannot, however, properly be tested for dichotomous health indicators. The absence of a significant contribution of the multiplicative interaction term of work pace and intellectual discretion does, however, fail to support the assumption of interaction between two main components of the "job demands-decision latitude" model when added to the logistic model.

Although the relationship of work pace with intellectual discretion remained significant after adjustment for physical stressors, adding physical stressors to the logistic model resulted in a reduction of the magnitude of the estimated odds ratios of (poor) intellectual discretion. A similar finding was reported by Theorell et al (29). This finding may be due to the fact that poor intellectual discretion, especially of monotonous work, is often associated with work which is either short-cycled or involves a high static (postural) load. This hypothesis should, however, be tested in a study in which the physical load is more elaborately operationalized.

Not only physical stressors but also personal characteristics reduced the odds ratios for (poor) intellectual discretion in the regression models. This reduction was probably due to the fact that women and older employees, and employees with little education, more often have work with poor intellectual discretion. The increase in the odds ratios for physical load when these characteristics are entered next into the model is, on the other hand, probably due to the fact that men and younger employees more often perform heavy work in a work environment which is physically loading $(16,17)$. Even after adjustment for the moderating effects of gender, age, and education level, the odds ratios of both the individual stressors, especially monotony, and the main risk dimensions for work stress generally remained significant.

Even after adjustment for physical load and personal characteristics, the odds ratios estimated for (poor) intellectual discretion were consistently found to be higher than those found for work pace. This finding suggests that the impact of intellectual discretion was larger than that of job demands. Two alternative explanations can be put forward. The first one is purely methodological in nature and concerns the number of questions asked to measure the con- cepts. The "demands" dimension was operationalized with one question only, whereas the "intellectual discretion" dimension was operationalized more extensively. The more questions asked, the more reliable the score and the more variance to explain (another concept) or to be explained. A second explanation can be found in recent findings of Theorell et al (30), which indicate that the perception of pain might be different under situations that differ in job demands and decision latitude. These researchers found that high demands are associated with an increase in pain threshold. Sympathetic activation might be the underlying physiological mechanism. An increase in pain threshold may result in the underreporting of health symptoms. Low intellectual discretion, on the other hand, was found to be associated with a lowering of the pain threshold, which, instead, might result in an increased tendency to report symptoms.

Before the conclusions of the present study are summarized, it must be kept in mind that this study was cross-sectional in nature. All significant relations do not necessarily indicate a causal relationship. As stated in the introduction, longitudinal studies which provide support for causal processes linking psychosocial stressors to musculoskeletal problems are, to our knowledge, unavailable. In addition, the strength of the relationships found in the present crosssectional study may, on one hand, be inflated by methodological problems such as recall bias. On the other hand, however, the strength of the relationships found might be reduced because of selection processes both into and out of professions, resulting in a selection of "fit" employees into specific jobs and a loss of those employees who leave jobs high in stress risk because of health problems they have developed over time.

To summarize, it can be stated that psychosocial stressors are not only associated with psychosomatic complaints and health indicators, but with musculoskeletal problems as well. Especially the relation between intellectual discretion and musculoskeletal problems can be partly attributed to physical load, although the exact nature of this confounding effect is not clear. Even after adjustment for physical stressors and moderating personal characteristics, the relationships between the psychosocial stressors and musculoskeletal problems remained significant and comparable in strength to the relationships between psychosocial stressors and several other health outcomes, like psychosomatic complaints and several health behaviors.

\section{References}

1. Karasek RA. Job demands, job decision latitude, and mental strain: implications for job redesign. Adm Sci Q 1979;24:285-308.

2. Schaufeli W. Burnout: Een overzicht van empirisch onderzoek [Burnout: a review of empirical evidence]. Gedrag Organ 1990;3:3-31. 
3. Larsson G, Setterlind S. Work load/work control and health: moderating effects of heredity, self-image, coping, and health behaviour. Int J Health Sci 1990;12:79-88.

4. Karasek RA, Theorell T, Schwartz JE, Schnall PL, Pieper CF, Michela JL. Job characteristics in relation to the prevalence of myocardial infarction in the US Health Examination Survey (HES) and the Health and Nutrition Examination Survey (HANES). Am J Public Health 1988;78:910-8.

5. Pieper C, LaCroix AZ, Karasek RA. The relation of psychosocial dimensions of work with coronary heart disease risk factors: a meta-analysis of five US data bases. Am J Epidemiol 1989;129:483-94.

6. Schnall PL, Pieper C, Schwartz JE, Karasek RA, Schlussel Y, Devereux RB, et al. The relationship between "job strain," workplace diastolic blood pressure, and left ventricular mass index. JAMA 1990;263: $1929-35$.

7. Siegrist J, Peter R, Junge A, Cremer P, Seidel D. Low status control, high effort at work and ischaemic heart disease: prospective evidence from blue-collar men. Soc Sci Med 1990;31:1127-34.

8. Van Egeren LF. The relationship between job strain and blood pressure at work, at home, and during sleep. Psychosom Med 1992;54:337-43.

9. Calibrese JR, Kling MA, Gold PW. Alterations in immunocompetence during stress, bereavement, and depression: focus on neuroendocrine regulation. Am J Psychiatry 1987; $144: 1123-34$

10. Sklar LS, Anisman H. Stress and cancer. Psychol Bull 1981;89:369-406.

11. Bongers PM, de Winter CR, Kompier MAJ, Hildebrandt VH. Psychosocial factors at work and musculoskeletal disease. Scand J Work Environ Health. 1993;19:297-312.

12. Joint Medical Service (GMD). Annual report 1991, Amsterdam: GMD, 1992.

13. Kelsey JF. Epidemiology of musculoskeletal disorders, New York, NY: Oxford University Press, 1982:3-11.

14. Theorell T. Psychosocial factors at work in the pathogenesis of symptoms from the locomotor system. In: Arbets Miljö Institutet: Abstract book from the International Scientific Conference on Prevention of WorkRelated Musculoskeletal Disorders PREMUS, Sweden, May 12-14 June. Stockholm: Arbets Miljö Institutet, 1992:18-22.

15. Netherlands Central Bureau of Statistics (CBS). De leefsituatie van de Nederlandse bevolking, deel 1: kerngegevens [The national work and living condition survey, part 1]. Den Haag: Staatsuitgeverij, 1979, 1984 \& 1987.

16. Bloemhoff A, Smulders PGW. Kwaliteit van de arbeid voor vrouwen en mannen: verschillen en trends in de periode 1977-1986 [Quality of work for men and women: differences and trends across the period 1977-1986]. Tijdschr Arb 1991;7:4-17.

17. Smulders PGW, Bloemhoff A. De kwaliteit van de ar- beid, gezondheid en welzijn in de toekomst [The quality of work, health and well-being in the future]. Utrecht: Bohn, Stafleu \& Van Loghem, 1991.

18. Houtman ILD, Bloemhoff A, Kompier MAJ, Marcelissen FHG. Werkstress risico's in bedrijf en beroep [Occupational and organisational risks for work stress]. Den Haag: Directoraat-Generaal van de Arbeid, Ministerie van SZW, 1991. (S-133.)

19. Jex SM. The psychological benefits of exercise in work settings: a review, critique, and dispositional model. Work Stress 1991;5:133-47.

20. Karasek RA, Theorell T. Healthy work. New York, NY: Basic Books, 1990.

21. Toomingas A, Theorell T, Michélsen H, Nordemar R. Associations between perceived psychosocial job factors and prevalence of musculoskeletal disorder in the neck and shoulder regions. In: Arbets Miljö Institutet. Abstract book from the International Scientific Conference on Prevention of Work-Related Musculoskeletal Disorders PREMUS, Sweden, May 12-14 June. Stockholm: Arbets Miljö Institutet, 1992:289-90.

22. Bosma H, Appels A, Sturmans F, Schuurman J, Mulder P. KRIS follow-up IX. Tijdschr Soc Gezondheid 1991;69:299-305.

23. Rosengren A, Tibblin G, Wilhelmsen L. Self-perceived psychological stress and incidence of coronary artery disease in middle-aged men. Am J Cardiol 1991;68: $1171-5$.

24. Johnson JV, Hall EM. Job strain, work place social support, and cardiovascular disease: a cross-sectional study of a random sample of the Swedish working population. Am J Public Health 1988;78:1336-42.

25. Schrameijer F. Sociale steun - analyse van een paradigma [Social support - analysis of a paradigm]. Utrecht: Nederlands centrum Geestelijke volksgezondheid, 1990.

26. Theorell T, Ahlberg-Hulten G, Sigala F, Perski A, Soderholm M. A psychosocial and biomedical comparison between men in six contrasting service occupations. Work Stress 1990;4:51-63.

27. Furda J, Meijman TF. Druk en dreiging, sturing of stress [Pressure and threat, control or stress]. In: Winnubst JAM, Schrabacq MJ, ed. Handboek arbeid en gezondheidspsychologie [Handbook work and health psychology]. Utrecht: Lemma, 1992:127-144.

28. Warr PB. Decision latitude, job demands, and employee well-being. Work Stress 1990;4:285-94.

29. Theorell T, Harms-Ringdahl K, Ahlberg-Hultén G, Westin B. Psychosocial job factors and symptoms from the locomotor system - a multicausal analysis. Scand J Rehabil Med 1991;23:165-73.

30. Theorell T, Nordemar R, Michélsen H. Pain threshold during standardized psychological stress in relation to perceived psychosocial work situation. J Psychosom Res 1993;37(3):299-305.

Received for publication: 18 January 1993 